\title{
VI THE ART OF BRACKETING EMPIRE OUT AND CREATING PARALLEL WORLDS: THE CASE OF LATE PERSIAN YEHUD
}

\author{
Ehud Ben Zvi \\ University of Alberta (emeritus)
}

\begin{abstract}
The goal of this article is to draw attention to a seemingly strange, generative pattern that, at times and under certain conditions, has shaped socially shared worlds of imagination among subordinate groups within imperial or hierarchically asymmetric structures of power, especially among "retainer" groups who saw themselves as a "cultural elite" of the subordinate group. I am referring to a generative pattern that in a significant number of such groups, across time and space, has led to constructions of worlds of imagination, and vicarious participation in them through readings or other social acts of imagination that involved "bracketing the empire out." The article focuses on the world of the literati of late Persian Yehud/Judah, and especially the bracketing out of Ramat Rahel, the most obvious and monumental, explicit, imperial site in the province, but a number of various examples from diverse historical and geographical contexts are also brought to bear to make a point that this is a well-instantiated pattern. The article then concludes with a discussion of what was often gained by acts of imagination and memory involved in bracketing out "empire" and under which circumstances such acts tended to be historically likely.
\end{abstract}

This article follows an approach I have developed elsewhere, and which is informed by both memory studies and some version of center/core-periphery studies (see, e.g., Ben Zvi 2016; 2019). ${ }^{1}$ For the present purposes, a brief, basic introduction suffices to introduce the reader to the general approach and then recapitulates some common processes and patterns of engagement between "empire" and local "cultural elites" and the generative tensions over the imaginary of the subordinates that tend to emerge under these sociocultural, hierarchical systems. This recapitulation sets the context for a study of the pattern mentioned above, for which a specific historical case involving the literati of the late Achaemenid Yehud (Judah) will be addressed as a test case and explored within the context of the literati's general approach to the Achaemenid Empire. This case is then shown to be an instantiation of a pattern at work across time and space, rather than an "odd" or even "unique" case. A number of various examples from diverse historical

1 Elsewhere I wrote: “Approaches informed by memory studies can be particularly helpful in terms of understanding processes of forgetting. Sites or sets of sites of collective memory evoke and shape particular memories; as they do so, they cannot but urge their visitors to forget or render dormant, or reduce the mindscape of some images, memories, associations and the like. But that which is remembered and forgotten stands at times interwoven in particular and significant ways" (Ben Zvi 2012b: 42). On these issues, see also Ben Zvi 2012a; Ben Zvi \& Levin 2012, and bibliography.

Volume 9(2) (2021), pp. 174-185

DOI $10.23993 /$ store. 89226

Licensed under Creative Commons 4.0 (CC BY-NC-SA 4.0) license. 
and geographical contexts are brought to bear and suffice to make the point. The article then concludes with a discussion of what was often gained by acts of imagination and memory involved in bracketing out "empire" and under which circumstances such acts tended to be historically likely. All in all, the purpose of this study is to draw attention to this type of social acts of imagination and world construction and thus encourage further, more detailed studies on this phenomenon from a cross-cultural perspective.

A good starting point for the general introduction promised above is the widely agreed upon fact that any social group, polity, community, and so forth, requires the existence of, inter alia, a set of social construed and socially shared memories about its past—and, I would add, its future - to maintain itself. Such memories are absolutely necessary for the group's social reproduction. The world of imagination that these memories construe shapes for the group a sense of a "reality" that encompasses a past, present, and future (and thus is cross-temporal) in which the group, polity, community imagined itself to be anchored.

When the group, polity, or community exists, as often is the case, within an asymmetrical, hierarchical system, the hegemonic side strives - and, from a systemic perspective, is only expected to strive - to achieve cultural hegemony. ${ }^{2}$ The highest expression of cultural hegemony is when the hegemonic side controls the imaginary of the subordinate groups. To be sure, this does not necessarily mean a push toward cultural homogeneity. On the contrary, and looking into ancient empires, one may mention, for example, "Hellenistic rulers did not simply tolerate but actively participated in the process of casting themselves in local cultural idioms and writing their empires into local histories" (Stevens 2016: 67) which certainly holds true for Babylonia and the Seleucids discussed by Stevens, but also, for instance, Achaemenid policies. Conversely, local elites tended to inscribe themselves and the empire ${ }^{3}$ within which they existed into local histories which stretched back to the distant past (Stevens 2016; see also the ways in which Cyrus was embedded in constructions of the past in Persian Yehud). ${ }^{4}$

The systemic preference for contributing to a sense of cultural locality by both the imperial local elite and the empire as such meant that full domination of the subaltern imaginary was not desirable for the hegemonic group. A system in which empire and local elites together shape the boundaries of the imaginary tends to be a more successful approach to ensure long-term imperial stability, as well as that of local elites.

The fact is that from the (systemic) outset full domination of the imaginary, including of the generative grammars producing socially construed and socially shared memories and even the system we may call the "reality" that is construed and perceived by the subordinate group carries a considerable cost for the hegemonic side, even if or when it might be possible to achieve such a control over the other's "reality." For one, such complete control would have a strong negative impact on the ability of the relevant subordinate group to socially reproduce and remain the "other," which is in itself a systemic necessity for the stability of most asymmetrical, hierarchical systems. Thus, from a systemic perspective, both compliance with, and some form of sociocultural resistance to cultural hegemony tend to be necessary for asym-

\footnotetext{
2 Of course, this "cultural hegemony" is not meant to erase local ideologies. To the contrary, since its sociopolitical role is to further the maintenance of hegemonic side's power through the consent of the non-hegemonic, it has to be responsive to important needs and cultural traditions of the latter. See below.

3 The concept of "empire" is itself open for discussion. For one possible and often cited definition of the term "empire" and a discussion of the large degree of variation among empires, see Sinopoli 1994: 160.

4 See also Stevens 2019 for the multiple ways and limitations associated with these processes.
} 
metrical, hierarchical systems to dynamically evolve and reach a substantial level of "stability." Empires tend to facilitate or allow both.

As we turn our attention to ancient empires, which are one of the obvious cases of these asymmetrical systems and the central focus of this set of articles, these considerations lead us to look into historical instantiations of these dynamic processes of engagement and the generative tensions over the imaginary of the subordinates. ${ }^{5}$ The center would always, though not necessarily always in the same way, tend to shape at least crucial aspects of the imaginary of the subordinate and peripheral and the latter would tend to reassert what it considers to be crucial aspects of its own imaginary, even if through the required reconfigurations emerging from its situation as a subordinate group in a particular imperial system. The center itself would tend to facilitate these local processes for its own systemic good.

Subordinate groups, and especially their cultural retainer classes often comprised of intellectual elites, tend to address the challenges of controlling, at least from their own viewpoint, their own social imaginaries in imperial settings and thus a sense of self-which is in itself a crucial part of their social imaginary - mainly through a number of familiar, transculturally well attested, past-shaping world-construing generative grammars.

Some of these common generative grammars involve appropriation and re-signification of crucial hegemonic ideas. Cultural resistance is often in these cases supported by a self-construction of the subordinate as superior to the hegemonic group in some key feature. I elaborated on such an instantiation of this general tendency elsewhere (Ben Zvi 2014). For the present purposes, it suffices to mention that this basic grammar might and did lead Persian-period Yehudites to imagine and vicariously experience through the world evoked and communicated through reading of the relevant texts, a future imperial world whose capital was in Jerusalem and whose king was YHWH. Nations will not flow to Persepolis but to Jerusalem. YHWH will govern the world as the King of Kings (not a human Persian king). Happiness to humankind will result from Tōrâ, not from the actions of the Persian king. Instead of an imperial court at whose very center were Persians and Medes, a new one of people serving directly the house of YHWH will emerge and it will consist of Israelites (Ben Zvi 2014).

A similar process, of course, took place among Egyptian Judeans in the Hellenistic period. Greek philosophy was an outstanding achievement and they as "Greeks" relished in it. But from their perspective, Greek philosophers learned from Moses. In fact, Judeans were from that perspective the most "original" Greeks, and not only was Judaism a "Greek" school but also a/ the foundational one. As Aristobulus stated, "Plato followed the tradition of the law that we use, and he obviously worked through each of the details expressed in it" (Holladay 1995: 125). ${ }^{6}$

A variant of this approach is to appropriate central images of the hegemonic power and closely associate them with divine selection of the subordinate, thus subverting the efficacy of hegemonic foundational narratives. Examples of this basic generative pattern for the developing of social memory among subordinates include the famous story of the Virgen of Guadalupe in

\footnotetext{
5 I would like to stress that these processes work both ways. The subordinate, including its imaginary, often impacts the world, identity, and social mindscape of the hegemonic, including its own imaginary. Examples of these processes within the Neo-Assyrian, Neo-Babylonian and Achaemenid Empires abound (see, e.g., the use of Aramaic in Assyria, etc.). That said, an analysis of the entire two-way system of mutually informing and mutually reconfiguring culture between imperial centers and local, peripheral centers is beyond the scope of an article where the focus is on a less discussed generative trend for world construction among some subordinates under particular historical circumstances.

6 On Aristobolus, see Mülke 2018 and on Alexandrian Judeans as 'the best of all Greeks,' see Honigman 2013.
} 
colonial Mexico, ${ }^{7}$ and in reference to the main periods and areas discussed here (e.g., the claims and memories in Yehud about the emergence of Cyrus as the great king) the emergence of what we call the Persian empire as the outcome of YHWH's will, and as a historical process that took place only for the sake of YHWH's servant, Jacob (Isa 45:1-4).

The last example is also integral to a related basic generative pattern for shaping social memory according to which the empire is remembered as stripped of causal agency, while such agency is strongly and repeatedly associated with the subordinate. For instance, in the world of memory of the Yehudite literati, monarchic-period Jerusalem and Judah fell not because of the greatness of Nebuchadnezzar or remained standing in the time of Sennacherib due to his wickedness, but due to Judahite actions. Judah had ultimate agency regarding its future. The Babylonians or the Assyrians did not have any independent agency around these matters, as only Judah and YHWH were imagined in the sense of truly independent agents.

Additional, familiar, grammatical, generative patterns are directly implicated in acts of balancing the acknowledged existence of some center-periphery axis in which the remembering group takes the position of periphery in the "actual world" with other axes in which the relation is inverted. Historically, multiple political peripheries imagined themselves as cultural centers (e.g., Greek thinkers in the Augustan era such as Dionysius of Halicarnassus). Turning to the period on which I focus, Yehudites imagined themselves to possess true knowledge about the world that was not available to the Persians and the Persian king. Polities with less economic or political capital often imagined themselves as holding more cultural capital and the like (see Ben Zvi 2016).

In addition, of course, the development of "national" histories and acts of imagination and memory recalling periods in the past in which a subordinate group was hegemonic over others all served, directly and indirectly, to support a sense of cultural resistance and contributed to social reproduction and vice versa. Social reproduction shaped supportive conditions for the generation and acceptance of "national histories" and of construing and recalling old periods of greatness that implicitly or explicitly shaped hopes and at times even expectations for future developments, even if in a faraway future. Instantiations of all of these grammars were ubiquitous among the literati of Yehud.

Against this background, as mentioned above, I would like to draw attention to another, seemingly strange generative pattern that shaped socially shared worlds of imagination among subordinates, namely, the constructions of worlds of imagination and vicarious participation through readings or other social acts of imagination that involved "bracketing the empire out." This pattern has been less studied than the other, more familiar ones, and there might be good reasons for that, but I doubt that it is so uncommon and it is certainly not unique to the particular historical group on which I specialize, that is, the Yehudite literati. On the contrary, as will be shown below, this pattern is well-attested transculturally, even if by necessity the specific outcomes of this trend are strongly contingent on the sociocultural, historical particularities of the group that construes the imaginary world in which to participate.

7 See especially Rodríguez \& Fortier 2007: 34-53. 
The most obvious instantiation of this generative pattern among the literati of Yehud concerns the imperial compound of Ramat Rahel in the Persian period. ${ }^{8}$ This massive, prominent, and administratively and politically key site in the "real" world of the Jerusalem-centered literati of the period is simply absent from the world that was encoded in and evoked through their readings and rereadings of their core, authoritative repertoire. . It was impossible for the literati to miss in the "real" world the most monumental compound of Yehud, and most likely the only monumental compound at the time standing a relatively short distance from Jerusalem. ${ }^{10}$ This compound served as the most visible site of memory that embodied and communicated "empire" for them, but significantly it was a site of memory absent of the memoryscape and imaginary land they recalled and evoked when reading their core literary-cultural, religious texts. ${ }^{11}$

8 I fondly remember an informal chat Gary Knoppers and I had about the lack of references to Ramat Rahel a few years ago. Perhaps this chat stimulated our thinking and led each one of us to eventually write about the topic, even if in different research contexts. As in some other occasions involving the two of us, although we used different approaches and asked distinct questions, it seems to me that we ended up with complementary and, even to an extent, mutually reinforcing studies. See Knoppers 2021. Regrettably, his work on the matter had to be published posthumously. I dedicate this article to him.

On Ramat Rahel and its importance in the Persian period, see the vast oeuvre of Oded Lipschits and his colleagues (Lipschits et al. 2011; 2012; 2017). The likely name of the place in the late Iron Age was Beit Hakerem (Jer 6:1). The place also served as a highly visible, imperial center, perhaps even the "palace" of the Assyrian qерu (see, e.g., Na'aman 2001) when the kingdom of Judah was a Neo-Assyrian vassal, centuries before the Persian period. Recently, Hays (2019: 125) has maintained that precisely because of its administrative roles and visibility, it "would have been a focal point for local resentment of imperial rule." He proposes that after the compound was abandoned by the Assyrians in the late years of Josiah (between 625 to $614 \mathrm{BCE}$ ), the place, without being named, is likely behind the references to the lofty city opposed to Jerusalem in Isa 24-27. This is not the place to discuss Hays' position on the matter, though it is worth mentioning that the date of Isa 24-27 is and has been for a long time a highly debated matter and that there is no explicit reference to Beit Hakerem in the text. That said, the logic of his argument raises the question why there exists no explicit reference to the even more commanding, imperial compound of Ramat Rahel of the Persian period, even in texts from that period or later, which purportedly report about the situation in Yehud and especially in Jerusalem and its surrounding areas (e.g., Haggai, Zechariah, Ezra-Nehemiah).

9 Most of the books and collections of books later included in the Hebrew Bible, with some exceptions (e.g., Daniel) provide a working, rough approximation of this repertoire.

10 About $4 \mathrm{~km}$. One cannot avoid mentioning that the absence of Ramat Rahel and its dominant presence at the time raises substantial questions about the use of, or at least about how to use any of these literary, ideological sources as "historical sources" for historical reconstructions of Achaemenid Yehud, but these methodological issues, as important as they may be, are beyond the scope of this contribution.

11 The fact that the literati did not literally see Ramat Rahel when they were at the Temple in Jerusalem might have facilitated their ability to imagine a world in which the empire is not "seen," despite their omnipresence and the geographical closeness of the majestic building proclaiming their presence and power. But not seeing or even unseeing does not require a ridge in between; it is an act of social construction of imaginary worlds and a social performance. Moreover, if they could not see it when at the temple, they could not but be aware of it, and its "majestic" character. Further, as it will be discussed below, "bracketing out" Ramat Rahel, as eye-opening as is, is not an anomaly. It is part and parcel of a large tendency to bracket out Persia and Persians that is widely attested in the literati's cultural core repertoire. No physical ridge played any part in this large world construction project. As an aside, but still an important one, it is worth stressing that "not seeing" the other works differently depending on the observers and their worlds, or at least the worlds in which the unseeing takes place. For instance, between Ramat Rahel and Persian period Jerusalem and the Temple Mount stood the ridge in which today stands the palace built for the British High Commissioner of Palestine during the Mandate. The fact that the Persian authorities did not care to build their headquarters in the area with a view of Jerusalem and the Temple, even if they were rebuilding and expanding on an earlier site, suggests that they thought that there was not such a need to watch over this area, and above all not much to watch. One may easily contrast this state of affairs with the situation in the Seleucid and Roman periods (see, e.g., the Akra in the former, and the Antonia Tower in the latter). The difference says much about the completely changed historical circumstances. 
The literati's ability to construct and "live" (when involved in reading these texts) in a world of imagination in which there is no Ramat Rahel shaped for them a landscape focused on Jerusalem, on the Temple, and, given the encyclopedic/world of knowledge of the group, on a world in which divine instruction (Tōrâ) and all the texts associated with it become absolutely central, and discursively absolute, in the sense that they became disassociated from any temporal conditions and powers. Conversely, since the validity of the divine instruction was understood as not dependent on any temporal power, then why even pay attention to them when reading and thinking of Tôrâ, unless absolutely necessary? A positive feedback loop thus emerged and contributed to a social preference and "taste" for an imaginary world in which the compound at Ramat Rahel was absent, and above all, for "experiencing" such a world. ${ }^{12}$ Further, under these conditions, this type of "imaginative walking" became a social performance that marked individuals as proper members of the group, advancing ingroup social cohesion, as done by all these "tastes" in similar situations.

It is worth stressing that it is only their current temporal power/empire and its main symbolic manifestation that are "bracketed out" in this world of imagination. Previous empires (e.g., Assyria, Babylon) are not. They are present and very much remembered. They serve as nodes of memory used for didactic purposes that bring together and communicate multiple ideological concerns of the literati. Moreover, they may be construed as teaching examples showing, inter alia, YHWH's control of the world, and the tragic cost associated with rejecting YHWH's instructions as understood and communicated by the literati.

Although the absence of Ramat Rahel's buildings and its monumental projection of Achaemenid power over Yehud represent an extreme case of bracketing present-day empire out among these literati, it was not an anomaly. Persia and Persians are notable for their tendency to be absent from the very corpus of core texts mentioned above. ${ }^{13}$ Certainly, compared to all the other "nations," references to Persia are minimal and most often focus on: (a) the emergence of the Persian empire as the outcome of YHWH's decision, for the sake of YHWH's people, Israel, and (b) their instrumental role for the rebuilding of the Davidic temple, though such references had to be balanced with many memories that encapsulated and communicated a sense that the building of the Temple was also a Judean enterprise (Ben Zvi 2014). All in all, this narrow range of references to Persia is not surprising, since if there is any room for the present empire at all within the kind of strange imaginary worlds mentioned above, it would be only to recall and communicate YHWH's control of the world, Jerusalem's importance, and the divine instruction on which the latter was grounded. ${ }^{14}$

\footnotetext{
12 I am using "taste" here in a Bourdieusian sense. On the relevance of this use for the study of the world of these literati, see Ben Zvi 2019: 631-654.

13 Of course, the Persian empire is certainly present in Ezra-Nehemiah, but this book is neither representative of the large core corpus nor likely belongs to the Achaemenid period-it dates most likely to the Hellenistic period. That said, even in Ezra-Nehemiah, Ramat Rahel is not mentioned. On this absence and from a different perspective, see Knoppers 2021. It is worth stressing that even if one were to argue that Ezra-Nehemiah partook in some minor way in the mentioned corpus, doing so would have no substantial bearing on the main argument advanced in this article.

14 The lack of explicit criticism and above all the lack of memories of announcements of punishment/judgment against Persia by YHWH in prophetic literature are salient features of the collection of prophetic books and stand in sharp contrast with the treatment allocated to Assyria and Babylonia, two empires of the past. The argument that the reason for the absence of negative references to Persia in inner Yehudite texts was due to the historical impossibility of criticizing the ruling power in such texts does not hold much water once comparative cases are brought to bear. On all these and related matters, see Ben Zvi 2014.
} 
In sum, the Yehudite, Jerusalem-centered literati of the Achaemenid period lived also in imaginary worlds that abstracted out substantial components of their "real" world. Of course, they did that as an act of will, cultural defiance, performance, construction of ingroup identity, cultural resistance, and the like, even if obviously they did so only in particular, ingroup social settings and only at times. The Persians in the "real" world were never far away. Further, one may assume that the literati's ability to enter and live from time to time in a world of imagination without their present empire likely contributed to their ability to actually accommodate the empire in their day-to-day life without the loss of their ability to socially reproduce. In fact, it is not unlikely that at least some of these literati interacted much with provincial authority, or even performed roles within it, as local retainer classes usually are.

To be sure, one case does not make a cross-cultural generative pattern. In what follows, I will draw attention to several other examples from ancient societies, from different places or periods. Obviously, it would be impossible in the present context to discuss any of these in any comprehensive way but demonstrating their presence would suffice to make the point.

One may reasonably argue, for instance, that the so-called "conservative" character of the cuneiform literature produced and reproduced in Seleucid Babylonia shaped a similarly construed world of imagination that communicated a strong sense of continuity with the past. It is worth noting that in this world of imagination, even when Seleucid kings do appear, they are culturally appropriated as much as feasible,${ }^{15}$ and current concerns are projected into a construed and remembered past in which no Seleucid king as such could be present (Waerzeggers 2015; De Breucker 2015; Jursa \& Debourse 2017). Allowing a semblance of continuity with the past in the world created in the minds of members of the priestly families responsible for the production and reproduction of cuneiform literature significantly contributed to their construction of a sense of identity, a sense of temple and textual-centered "Babylonian-ness," and a sense of the importance of their cultural and temple related roles, as well as the importance of the temple. As it did so, their cuneiform textual repertoire contributed to the construction of a world of imagination in which the Seleucid Empire was perhaps (and implicitly) addressed almost everywhere, but also one in which the Seleucid empire as such was for the most part nowhere. It is worth noting that this process or world construction and the vicarious participating in it through reading went hand in hand with close engagement not only with empire, both in general and in its structures, but also with its cultural court world (see, e.g., Kosmin 2013; Haubold 2016; Stevens 2016). Finally, this world of imagination is one that facilitated the social reproduction of the priestly literati and their temples, and thus the maintenance of a cultural distinctiveness that contributed in various ways to the Seleucid Empire itself (see, e.g., Haubold 2016). Much recent research has been devoted to Seleucid-period Babylonia and its priestly literati, and although the discussion above is extremely cursory, further exploration of these issues is beyond the scope of this article. That said, the discussion above suffices to show that similar, basic patterns for generating worlds of imagination were at work in both Seleucid Babylonia and Achaemenid Yehud. ${ }^{16}$

For the present purposes, it is important to shift our attention to a different period and a different group: it is worth noting that although Roman presence was omnipresent in the "real" world of Rabbi Judah the Prince (and his predecessors), and of the rabbinic movement of the

15 See, e.g., the Antiochos Cylinder; see Strootman 2013 and bibliography.

16 For additional, seemingly shared basic generative grammars of social memory, see Ben Zvi 2021. 
third and fourth centuries CE, explicitly Roman presence is actually minimal in the Mishna. In the world of imagination evoked by the Mishna and by readings of the Mishna among the Rabbis of the third century CE, "paganism" was everywhere, but "Rome," its military forces, and the like are strangely absent, unlike their clear presence in the later Talmuds. ${ }^{17}$

This is even more interesting given that the rabbis "are best understood as shaping their texts and their religious, social, and political stances as Roman provincials," (Lapin 2012: 3) that they represent "one mode of ethnic, urban, provincial association in a Roman province" (Lapin 2012: 88). They were part and parcel of a provincial structure that contributed to the social and political stability of the province, and their services as functionaries (though not "authorities") were allowed or facilitated by Roman power and structures of power and directly and indirectly served them. They were comfortable with the Roman provincial system, not unlike the literati of the Persian-period Yehud. Moreover, in both cases, the social and cultural capital of these two types of literati also depended on the support they could gather from their larger ethnic/ cultural ingroup, which for obvious reasons they socialized with, or attempted to, in ways that backed their importance as "guardians" and teachers of the Tōrâ, as they understood it to be, for the community (Schwartz 2001: 103-128).

In sum, reading the Mishna, "living" as it were through acts of imagination in the world evoked by its reading, meant construing a world in which the rabbis of the time, their ideas, and their social roles were absolutely central for Jews. The Romans' absence from this imaginary world contributed to its message, even if the presence of the empire itself was instrumental in its social emergence, given that, at the very least, without its presence the rabbis would not have developed their central communal position. Conversely, the Patriarch and the rabbinic movement of the time contributed to the stability of the imperial province (Lapin 2012). ${ }^{18}$

A similar basic generative grammar of "bracketing out" the more powerful "other" was at work in the case of a very different group, namely, the so-called "last pagans of Rome." The "Rome" of Q. Aurelius Symmachus (c.340-402 CE) and his group of intellectual aristocrats was for the most part an imaginary, idealized Rome of the past. This Rome, with which they saw themselves in continuation and even at least partially as embodiments, was not their present Rome. Christianity had, of course, no place in their remembered Rome. ${ }^{19}$

Moreover, whether Macrobius's later Saturnalia, in which Symmachus and some well-known figures appear as literary characters, construed a pagan world of imagination or just a world of imagination in which "classical" (i.e., proper "Roman"), antiquarian culture was omnipresent in the minds, speech, and behaviors of imagined pagan participants from Macrobius's recent past, if one accepts Alan Cameron's approach, his words are worth keeping in mind:

if the book [Macrobius, Saturnalia] has a pagan agenda, why is its paganisms relentlessly antiquarian? The first subject discussed by this notorious band of pagans is the genitive plural of the word Saturnalia. Why no reference to the state of those same festivals in the fourth century? Why (above all) no hint of Christianity? (Cameron 2011: 225) ${ }^{20}$

17 For a rare reference to a Roman governor of Syria in the Mishna, see m. 'Ed. 7:7: namely, "there was such a case with Rabban Gamaliel who went to take authorization from the governor in Syria and he delayed in coming back." 18 Conditions eventually changed a few centuries after the production of the Mishna. I am grateful to Prof. Jack $\mathrm{N}$. Lightstone for a conversation on this matter.

19 It is worth stressing that precisely these circles were very much involved in public struggles with influential Christian leaders (e.g., Ambrose, the famous Bishop of Milan). See, e.g., Evenepoel 1998-1999. This holds true even if their relations with other aristocratic Roman Christians of the time were relatively positive.

20 On Cameron's approach to Macrobius and the "pagan" culture of his age, see Cameron 2011: 231-272. 
The point for the present purposes is that in either case, the outcome remains a world of imagination in which stark markers of what is construed to be strongly negative historical change are absent. Depending on the interpretation, the group consists of "pagans" or of scholars who mourn the lack of appreciation for "proper classical culture" and its impact on society in its general milieu, but either case the world generation process and the mental travel to these worlds serve similar memory-shaping processes.

To be sure, the last two examples from the late Roman period push the temporal boundaries of the previously mentioned instantiations of the model (i.e., beyond Selucid or Achaemenid periods). This is precisely the point, namely, that the approach advanced here is flexible enough to offer at least heuristically helpful considerations about vastly different groups and cultures. It is in this context that I would like to raise some observations about an even more distant society from the first three discussed here, to illustrate the heuristic value of this approach for comparative studies of history and memory.

It is difficult to argue that the entrenched resistance to reforming the Chinese Imperial Civil Examination System (and to some extent even the military examination system ${ }^{21}$ ) in the late nineteenth and twentieth centuries had nothing to do with a strong unwillingness to let go of a world at whose center were traditional, classical Chinese texts and culture among very influential groups in the late Qing court. After all, the main debate at the time was not on whether a person who does well in learning should take office, but what such a person should learn well to serve in office. The crux of the debate was about curriculum and what constitutes worthy learning in this context, and thus to a large extent about shaping and participation in shared worlds of knowledge, memory, and imagination..$^{22}$ The system of examinations and the very act of studying for the exams in a centuries-old process shaped a world in which cultural discontinuity and the presence of the Western powers, so evident in China at that time, were if not bracketed out, at least strongly tempered by a strong emphasis on Chinese cultural tradition. ${ }^{23}$

From a comparative perspective, it is worth noting that despite all their differences, all these full or partial instantiations of this generative pattern carry an element of (resistance) utopianism, and one may assume even hope. As usual, the ways in which utopianism develops in a particular group have much to do with its historical, contingent conditions, and yet, as noticed above some basic generative patterns seems to be cross-cultural.

Significantly, the mentioned patterns themselves are not always attested. They seem to be historically contingent. It is easy to notice that empire was indeed bracketed out in the central literary repertoire of Achaemenid Yehud, but not so in that of Hellenist Judah and particularly in the Seleucid times. Romans are indeed to a large extent absent from the world evoked by the Mishna, but certainly not from that of later rabbinic literature (e.g., the Talmuds). Cuneiform literature in Hellenistic times did not transition into a textual repertoire in which empire was

\footnotetext{
21 See note below.

22 To be sure, as is usually the case under such circumstances of drastic social and cultural change under colonialism, the relative value of traditional social institutions of learning (e.g., traditional academies) was under severe critique as well.

23 It is worth mentioning that the Examination System, which served as a kind of symbol of all that was wrong with "traditional" China almost since it was abolished, if not before, has been reevaluated in China in the last decades. This goes together with an increased emphasis on the social value of traditional Chinese texts and of studying them. In fact, some have considered the Examination System to be the fifth great invention of ancient China, alongside papermaking, gunpowder, printing, and the compass. For literature on the Examination System from different research perspectives, see Elman 2000; 2013; Wang 2013; Liu 2018.
} 
prominently present, as was the case for Judeans in the Hasmonean and early Roman periods, or for Late Antiquity Jews when "imperial Christianity" evolved and reconfigured, along with other factors, their world/s by the time the Talmuds emerged. As for the other examples, worlds of imagination that were developed by the "late pagans" of Rome disappeared along with "paganism," and the Chinese Imperial Examination System was cancelled in the early twentieth century.

It seems thus that "abstracting the empire out" and related patterns involving powerful "strangers" are associated with particular historical conditions, at least as understood by the group involved in the abstracting. The required acts of imagination and of memory construction seem far more likely to take place and be socially reproduced when accommodation with the hegemonic power in the "real" world was seen as possible. In particular, when subordinate groups understood both their acts of imagination and accommodation with hegemonic power as, or even, necessary for their own processes of social identity and social reproduction. For this to happen, the hegemonic power has to be understood by the subordinate group as not interested in or even likely to ever threaten them with their demise. The "bracketing out" group has to be able to construe it, at least partially, as a "real world" facilitating factor for their continuous existence. This is more likely to occur when the subordinate group consists of intellectual elites engaging empire in their own multivocal ways and along multiple axes. To be sure, this is a subjective evaluation shared among the subordinate group, but at times it also reflects a deeply held understanding of the ingroup about their own situation. The literary discourse of Persian Yehud was not one characterized by "existential anxiety." ${ }^{24}$ The days of Rabbi Judah the Prince were, at least from the perspective of those close to him, a high point compared with recent history.

What is necessary in these cases seems to be a mutually supportive interweaving of these perceived circumstances with ongoing ingroup tendencies towards, inter alia: (a) appropriation of images of empire, and cultural and ideological resistance to it, (b) inscriptions of empire within the "historical" narrative of the group and thus ideological "normalization" of its presence, (c) self-affirmations of their ingroup knowledge grounded in self-constructions in which they imagine themselves as possessing "true" knowledge (or "true culture") that the hegemonic group lacks, and (d) at times ongoing acts of construing empires of the future that partially resemble the one under which they live, but which are imagined as far more powerful, or even eternal, and most importantly, ones in which their own ingroup would be at the very center rather than their current hegemonic power. ${ }^{25}$

Conversely, one may reasonably argue that the presence of this seemingly strange generative pattern of "bracketing empire out" as demonstrated by well-attested historical instantiations of relevant worlds of imagination may also serve as a potential window into the subjective historical situation of a subordinate group, even when its "objective" situation may look to us as drastically different and as a heuristic tool for exploring the possibility that related ingroup attitudes, sociocultural and ideological tendencies, and socially shared ingroup constructions of themselves and others and associated social memories may also be at work.

I hope that this article will draw attention not only to the test case of Achaemenid Yehud, but to a larger pattern that seems to be attested across cultures, historical periods, and geographical

24 This is a point I have made in several publications. See, e.g., Ben Zvi 2019: 39-45.

25 I discussed these matters in relation to Yehud's literati in Ben Zvi 2014. 
regions in the ancient world, and beyond it (see, e.g., the case of the Chinese Imperial Civil Examination System) and lead to further research on this generative pattern itself and the question of additional such patterns.

\section{REFERENCES}

Ben Zvi, Ehud 2012a. The Study of Forgetting and the Forgotten in Ancient Israelite Discourse/s: Observations and Test Cases. In: P. Carstens, T.B. Hasselbach \& N.P. Lemche (eds), Cultural Memory in Biblical Exegesis: 139-157. Piscataway, NJ: Gorgias Press.

Ben Zvi, Ehud 2012b. Remembering the Prophets through the Reading and Rereading of a Collection of Prophetic Books in Yehud. In: E. Ben ZvI \& C. LeVIN (eds): 17-44.

Ben Zvi, Ehud 2014. The Yehudite Collection of Prophetic Books and Imperial Contexts: Some Observations. In: A. LenZI \& J. STÖKL (eds), Divination, Politics and Ancient Near Eastern Texts: 145-169. Atlanta: SBL Press..

Ben Zvi, Ehud 2016. Introductory Centre/Core-Periphery Considerations and the Case of Interplaying of Rigid and Flexible Constructions of Centre and Periphery among the Literati of the Late Persian/Early Hellenistic Period. In: E. Ben Zvi \& C. Levin (eds) Centres and Peripheries in the Early Second Temple Period: 21-41. Tübingen: Mohr-Siebeck.

Ben ZVI, Ehud 2019. Social Memory Among the Literati of Yehud. Berlin: De Gruyter.

Ben Zvi, Ehud 2021. Leadership in the World of Memories Evoked by Chronicles in the Context of the Late Persian/Early Hellenistic Period. In: K. Pyschny \& S. Schulz (eds), Transforming Authority: Concepts of Leadership in Prophetic and Chronistic Literature: 185-200. Berlin: De Gruyter.

Ben Zvi, Ehud \& Christoph Levin (eds) 2012. Remembering and Forgetting in Early Second Temple Judah. Tübingen: Mohr-Siebeck.

Cameron, Alan 2011. The Last Pagans of Rome. NY: OUP.

EvenEPoel, Willy 1998-1999. Ambrose vs. Symmachus: Christians and Pagans in AD 384. Ancient Society 29: 283-306.

De BReuCKer, Geert 2015. Heroes and Sinners: Babylonian Kings in Cuneiform Historiography of the Persian and Hellenistic Periods. In: J.M. Silverman \& C. WAerzeggers (eds), Political Memory in and after the Persian Empire: 75-94. Atlanta: SBL Press.

Elman, Benjamin A. 2000. A Cultural History of Civil Examinations in Late Imperial China. Berkeley: UC Press.

Elman, Benjamin A. 2013. Civil Examinations and Meritocracy in Late Imperial China. Cambridge, MA: HUP.

HAYs, Christopher 2019. The Origins of Isaiah 24-27: Josiah's Festival Scroll for the Fall of Assyria. Cambridge, UK: CUP.

HAUBOLD, Johannes 2016. Hellenism, Cosmopolitanism, and the Role of Babylonian Elites in the Seleucid Empire. In: M. Lavan, R.E. Payne \& J. Weisweiler (eds), Cosmopolitanism and Empire: Universal Rulers, Local Elites, and Cultural Integration in the Ancient Near East and Mediterranean: 89-102. Oxford: OUP.

Holladay, Carl R. 1995. Fragments from Hellenistic Jewish Authors, III: Aristobulus. Atlanta: Scholars Press.

Honigman, Sylvie 2013. 'Jews as the Best of All Greeks': Cultural Competition in the Literary Works of Alexandrian Judaeans of the Hellenistic Period. In: E. Stavrianopoulou (ed.), Shifting Social Imaginaries in the Hellenistic Period: Narrations, Practices and Images: 207-232. Leiden: Brill.

Jursa, Michael \& Céline Debourse 2017. A Babylonian Priestly Martyr, a King-like Priest, and the Nature of Late Babylonian Priestly Literature. Wiener Zeitschrift für die Kunde des Morgenlandes 107: 77-98.

KNoppers, Gary N. 2021. Argumentum e silentio? Mizpah and Ramat Rahel in Ezra-Nehemiah. In: G.N. Knoppers (posthumously ed. C.M. Maier \& H.G.M. Williamson), Prophets, Priests, Promises: Essays on the Deuteronomistic History, Chronicles, and Ezra-Nehemiah: 392-407. Leiden: Brill.

Kosmin, Paul 2013. Seleucid Ethnography and Indigenous Kingship: The Babylonian Education of Antiochus I. In: J. Haubold, G.B. Lanfranchi, R. Rollinger \& J.M. Steele (eds), The World of Berossos: 199-212. Wiesbaden: Harrassowitz.

LApIN, Hayim 2012. Rabbis as Romans: The Rabbinic Movement in Palestine, 100-400 CE. Oxford: OUP.

Lipschits, Oded, Yuval Gadot, Benjamin Arubas \& Manfred Oeming 2011. Palace and Village, Paradise and Oblivion: Unraveling the Riddles of Rahel. Near Eastern Archaeology 74: 2-49. 
Lipschits, Oded, Yuval Gadot, Benjamin Arubas \& Manfred Oeming 2017. What Are the Stones Whispering? Ramat Rahel: 3000 years of Forgotten History. Winona Lake, IN: Eisenbrauns.

Lipschits, Oded, Yuval Gadot \& Dafna Langgut 2012. The Riddle of Ramat Rahel: The Archaeology of a Royal Persian Period Edifice. Trans 41: 57-79.

Liu, Haifeng 2018. The Examination Culture in Imperial China. Tr. Yu Weihua. Reading, UK: Paths International.

MüLKE, Markus 2018. Aristobulos in Alexandria. Jüdische Bibelexegese zwischen Griechen und Ägyptern unter Ptolemaios VI. Philometor. Berlin: De Gruyter.

NA'aman, Nadav 2001. An Assyrian Residence at Ramat Rahel? Tel Aviv 28: 260-280.

Rodríguez Jeanette \& Ted ForTIER 2007. Cultural Memory. Resistance, Faith and Identity. Austin: University of Texas Press.

Schwartz, Seth 2001. Imperialism and Jewish Society, 200 BCE to 640 CE. Princeton: PUP.

Sinopoli, Carla M. 1994. The Archaeology of Empires. Annual Review of Anthropology 23: 159-180.

Stevens, Kathryn 2016. Empire Begins at Home: Local Elites and Imperial Ideologies in Hellenistic Greece and Babylonia. In: M. LAVAn, R.E. PAyne \& J. Weisweiler (eds), Cosmopolitanism and Empire: Universal Rulers, Local Elites, and Cultural Integration in the Ancient Near East and Mediterranean: 65-88. Oxford: OUP.

Stevens, Kathryn 2019. Between Greece and Babylonia: Hellenistic Intellectual History in Cross-Cultural Perspective. Cambridge, UK: CUP.

Strootman, Rolf 2013. Babylonian, Macedonian, King of the World: The Antiochos Cylinder from Borsippa and Seleukid Imperial. In: E. Stavrianopoulou (ed.), Shifting Social Imaginaries in the Hellenistic Period: Narrations, Practices, and Images: 67-97. Leiden: Brill.

Waerzeggers, Caroline 2015. Facts, Propaganda or History? Shaping Political Memory in the Nabonidus Chronicle. In: J.M. Silverman \& C. Waerzeggers (eds), Political Memory in and after the Persian Empire: 95-124. Atlanta: SBL Press.

WANG, Rui 2013. The Chinese Imperial Examination System: An Annotated Bibliography. Lanham: Scarecrow Press. 